JIMA

8,2

204

Received 30 June 2015

Revised 30 August 2015

11 October 2015

23 October 2015

Accepted 16 November 2015

\title{
Frugal doesn't mean ordinary: a religious perspective
}

\author{
Volkan Yeniaras \\ College of Business Administration, Department of Management, \\ University of Sharjah, Sharjah, United Arab Emirates, and \\ Tugra Nazli Akarsu \\ Department of Marketing, Branding and Tourism, Business School, \\ Middlesex University, London, UK
}

\begin{abstract}
Purpose - Exchange is often identified as the primary role of marketing. Consumer behaviour literature, therefore, focuses on uncovering the characteristics of decision-making styles of individuals that embrace consuming. However, recent global economic crises have led consumers to become increasingly frugal. Approaching frugality from the religious perspective, this paper aims to identify the deep-level diversities of frugal consumers in their quality consciousness tendencies, rather than simply equating both frugality and religiosity to non-consumption.

Design/methodology/approach - In this paper, a counterintuitive model has been offered that includes the positive moderating effect of religiosity on the relationship between frugality and quality consciousness. Using structural equation modelling, this paper tests the proposed model using a unique sample of 413 adults. Findings - This paper extends the knowledge in the consumer behaviour literature by providing empirical evidence that religiosity positively moderates the relationship of frugality to quality consciousness. Further scrutiny showed that at high levels of religiosity, frugality positively affects quality consciousness.

Originality/value - This paper offers new avenues of research by highlighting the importance of not equating frugality and religiosity to low levels of consumption and abstinence from consuming. The dynamic nature of the growing Islamic economy requires both the scholars and practitioners to comprehend the consumers' consumption preferences in markets where religious beliefs and frugality are well embedded into the culture. The paper sheds light on the literature pertinent to the examination of the relationship between frugality and religiosity by suggesting that the highly religious Muslim consumers' frugality translates into quality consciousness.
\end{abstract}

Keywords Turkey, The Muslim consumer, Religiosity, Quality consciousness, Frugality

Paper type Research paper

\section{Introduction}

In 2008, the world has seen the worst financial crisis since the Great Depression of the 1930s. The start of this recession of which the effects are still evident, originated from the bursting of the US housing bubble that had peaked in 2007 (Kotz, 2009). The fall of the housing prices caused the values of the securities tied to US real estate to fall significantly. The effect of this was not limited to the USA only but was felt worldwide. This severe economic crisis that continues to this day, has obliged many consumers to become increasingly frugal (Birkner, 2013; Egol et al., 2010). Subsequent to Lastovicka et al.'s (1999) article that identified frugality as a largely neglected phenomenon both in consumer research and marketing literature, recent research started to scrutinize its antecedents and consequences (Albinsson et al., 2010; Rick et al., 2008). Defined as "a unidimensional consumer lifestyle trait characterized by the degree to which consumers are both restrained in acquiring and in-resourcefully using economics goods and services to achieve longer-term goals (Lastovicka et al., 1999, p. 88), 
frugality has recently attracted marketers' interest as a new market segment (Rick et al., 2008).

Said (1978), in his book Orientalism, showed the Western view of Islam and Muslims as irrational and weak while treating West to be rational and strong. Sandikci (2011) suggests that this predominated Western view of Islam served to marginalize Islam as an ideology that is incompatible with consumption. Accordingly, the conventional literature as it relates to the scrutiny of Islam and consumption preferences widely associates Islam with anti-consumption, anti-capitalistic, anti-Western ethos (Ahmed and Sara, 2004; Gellner, Frugal doesn't mean ordinary 1992) and anti-consumerism (Turner, 1994). This marginalization of Islam and the Muslim consumer as an ideology and a market segment that reject consumption absolutely, approached Muslims as the bottom-of-the-pyramid (Prahalad, 2004): a group of consumers that is not worthy of attention economically or scholarly.

An important poll conducted by Pew Research Center (2013) showed that the Muslim consumptionscape has reached US $\$ 2.7 \mathrm{tn}$. A more thorough report published by Reuters and Standard (2014) in collaboration estimate the food and lifestyle expenditures in the global Islamic economy that has reached US\$2tn in 2013 to increase to US $\$ 3.735$ tn by 2019 . One may observe the expectation of larger Islamic consumptionscapes in various domains such as travel industry (expected to increase to US\$238bn in 2019 from US\$140bn), media and recreation industry (expected to increase to US\$301bn in 2019 from US\$185bn) and fashion industry (expected to increase to US\$484bn in 2019 from US\$266bn). These reports that focus on the global Islamic economy provide sufficient evidence to suggest that the Muslim consumers should not be considered as the bottom-of-the-pyramid. Additional consultancy reports highlighted the importance of the Muslim market (Kearney, 2007; JWT, 2009; Ogilvy and Mather, 2010). One of the most prominent consultancy reports published by Ogilvy and Mather (2010) gives a unique perspective of the rising Muslim consumptionscape by providing evidence of global firms such as Tesco, Nestle, Coca-Cola and Unilever investing in Muslim countries. In light of these recent developments, research on Muslim consumers' consumption practices has begun to intensify not only in specialized marketing journals (Teimourpour and Heidarzadeh Hanzaee, 2011; Riquelme et al., 2011; Amin et al., 2014) but also in conventional marketing and business journals (Sandikci and Ger, 2002, 2010; Essoo and Dibb, 2004; Mokhlis, 2009). This interest is not only specific to marketing but also to economics (Hasan, 2006; Khan, 1984, 1991) and finance (Kahf, 2002, 2004).

The literature pertinent to consumption practices of Muslims seems to neglect the fact that Islam, along with other religions and belief systems such as Judaism, Christianity, Buddhism, Taoism and Hinduism (Lastovicka et al., 1999), entails abstinence from excess consumption and is associated with frugality (Flynn and Goldsmith, 2016; Lastovicka et al., 1999; Todd and Lawson, 2003). Support for the scholarly arguments on Islam's stance for moderation in consumption may be found in Quran itself (102:1): "[...] for piling up worldly things diverts you" (Quran 102: 1). Additionally, Islam also advises not to waste (israf) (Hasan, 2005; Kahf, 1992a, 1992b). Wilson and Hollensen (2013) suggest that there exists a quantifiable reward system where the adherents follow a methodological approach by relying on both the Qur'an and sayings and the practices of the Prophet Muhammad. While there is no doubt that the Muslims still rely on their religious principles, one should also take the recent phenomena that happen in the Muslim world. Wilson et al. (2013) suggest that several factors which include the rise in: Western university satellite campuses in Muslim countries, halal-approved commodities, Islamic finance and banking systems[1] have reshaped the Muslim consumptionscape and the attitudes towards consuming. Wilson et al. (2013) also argue that the Islamic modesty does not necessarily equate to anonymity, frugality or shyness. Modesty that has been redefined, according to Wilson et al. (2013), 
JIMA

8,2

206

changed the Muslims' perception of modesty from misery equalling piety to modest visible beauty and aesthetic attractive beauty.

Considering the recent phenomena highlighted by Wilson et al. (2013), this article makes an attempt to explain the role of Islamic religiosity in consumption preferences and adopts Lastovicka et al.'s (1999) religious perspective of frugality. Considering that moderation is well embedded in Muslims' consumption practices, though in a metamorphosis it is evident, and that the recent economic developments have made consumers become increasingly frugal, to understand the consequences of frugality (redefined modesty) of Muslims as it relates to consuming is crucial.

This paper's aim is to identify the fundamental consumer decision-making characteristics of frugal Muslim consumers, once labelled as the bottom-of-the-pyramid, may help marketing managers who wish to appeal to this segment. Thus, the purpose of the present study, considering that religiosity leads to moderation in consumption and resourcefully using economic goods and services (Lastovicka et al., 1999), is to investigate the hypothesized relationships between religiosity, frugality and quality consciousness. Conclusively, this study makes an attempt to identify the deep-level diversities (Harrison et al., 1998) in quality consciousness by encapsulating religiosity and frugality.

\section{Theoretical background and hypothesized model \\ 2.1 Frugality and quality consciousness}

Kotler (1972) and Bagozzi (1978) identify exchange as the primary role of marketing. Therefore, the focus has traditionally been on the scrutiny of the needs, wants and preferences of customers who embrace consuming in general. A relatively new stream of research, however, put forward the argument that marketing scholars should also consider the stated preferences of those who chose to go against consumption (Zavestoski, 2002) worthy of study. Similarly, Cherrier (2009) suggested that researchers should consider how and why individuals resist consumption and the manifestation of this trait. Extant literature commonly classifies frugal consumers as less materialistic individuals (Lastovicka et al., 1999; Richins and Dawson, 1992; Rose et al., 2010) who buy less (Lastovicka et al., 1999; Rose et al., 2010) and less likely to engage in compulsive purchasing (Faber and O'Guinn, 1992; Youn and Faber, 2000) by focusing more on frugal consumers' restraint from acquiring possessions than it does on their resourceful use.

Frugality refers to an ideal of attaining high life quality with low levels of consumption (Bouckaert et al., 2008). The literature simply equates frugality to low levels of consumption and abstinence from consuming. However, frugality, as put by Lastovicka et al. (1999), is not deprivation from consuming, but it is simply scarifying whims for the purpose of achieving a more worthy goal. This conceptualization of frugality alone implies an eventual quality quest at the expense of having to temporarily abstain from consuming. Although Lastovicka et al. (1999) and Shoham and Brenèiè (2004) suggest that frugality is related to value consciousness, it may be that these studies have captured the temporary abstinence of frugal consumers from consumption where they have concerns for lower prices subject to some quality limitations for the purpose of an eventual attainment to quality. Frugal consumers' desire to attain eventual quality may stem from their quality consciousness. Defined as "a characteristic measuring the degree to which consumer searches carefully and systematically for the best quality in products" (Sproles and Kendall, 1986, p. 54), quality consciousness may be a consumer characteristic of the frugal.

The insignificant relationship between frugality and coupon proneness (Lichtenstein et al., 1990) defined as "an increased propensity to respond to a purchase offer because the coupon form of the purchase offer positively affects purchase evaluations" (Lichtenstein 
et al., 1990, p. 56) shows that purchasing at lower prices is not an end but a means to an end for the frugal. Frugal consumers would be more coupon-prone if they gave precedence to lower prices. The significant relationship between frugality and value consciousness and the insignificant relationship between frugality and coupon-proneness provides evidence to suggest that frugal consumers prioritize the specific quality requirements that they have more than the prices. Economic stagnation that has led consumers to question the worth of material growth and to resort to simplicity and functionalism (Shama, 1981) does not seem to have consumers to forgo their quest of quality products. Considering that frugal consumers temporarily refrain from consumption to attain quality eventually and that they prioritize quality over price, the following hypothesis was constructed:

H1. Frugality positively and directly affects quality consciousness.

\subsection{Religiosity and quality consciousness}

Religiosity, defined as a belief accompanied by a pledge to follow particular principles to be set by God (McDaniel and Burnett, 1990), spreads through the value structure of a society (Essoo and Dibb, 2004; Inglehart and Baker, 2000). To assess the effect of religiosity on consumer behaviour, various studies have investigated the influence of religiosity on consumer shopping style in different cultural settings in different religions (Engel, 1976; Bailey and Sood, 1993; Sood and Nasu, 1995; Essoo and Dibb, 2004; Mokhlis, 2009, 2010). The literature pertinent to the scrutiny of the relationship between Islamic religiosity and various consumer behaviours widely associates Islam with rejection of consumption and anti-capitalism despite recent research suggesting that affluent religious middle engage in middle-class consumption and that they construct their identities by it (Fealy and White, 2008; Ger and Sandikci, 2010; Fischer, 2008; Pink, 2010).

In parallel with the Quranic verses that order Muslims to wear their best-quality clothes (for when they visit the mosque) but not to waste by excess (Araf 7: 31), Islamic religiosity found to be positively related to quality consciousness in various research settings (Mokhlis, 2009; Yousaf and Malik, 2013). The association between religiosity and quality consciousness is not only limited to Islamic religiosity. Essoo and Dibb (2004) revealed that Catholics also assign importance to the quality of products. Religiosity and frugality, although frequently associated with anti-consumption, in fact, condemn waste as opposed to consumption itself. The extent to which individuals are committed to their religion and its teachings would therefore translate into attitudes and behaviours that reflect their commitment (Johnson et al., 2001). A similar argument, suggesting that individuals with strong commitment to their belief systems would be both attitudinally and behaviourally inclined to make decisions consistent with moral conscience, was also put forward by Sood and Nasu (1995).

Examples of the relationship between religiosity and quality consciousness may be multiplied. In a study on the importance that consumers assign to various retail department store attributes, McDaniel and Burnett (1990) concluded that consumers with higher religiosity levels assign greater importance to product quality than those with low religious commitment. A cross-national study on the religiosity-buying behaviour association, Sood and Nasu (1995) showed that devout Protestants in the USA are more quality-conscious than the Japanese. Similarly, Mokhlis (2009) investigated the effect of religiosity on shopping orientations in Malaysia and concluded that the highly religious individuals look for quality in products when they shop.

The underlying argument of religiosity-quality consciousness association stems from the idea that people with a high degree of religiosity tend to be more positive regarding their quality of life (Hadaway and Roof, 1978), which leads religious individuals to be 
JIMA

8,2

208

quality-conscious to enhance their future welfare and lead to maximal pleasure in the long term (Bouckaert et al., 2008). Considering that the teachings of Islam encourage quality consciousness while condemning wasting by excessive consumption, the following hypothesis was constructed:

H2. Religiosity positively and directly affects quality consciousness.

\subsection{Moderating effect of religiosity on frugality-quality consciousness association}

Turning to the central constructs in this study, Lastovicka et al.'s (1999) religious perspective to explain consumer frugality was adopted, but in a different light. Frugality is well rooted in our human past (Wilk, 1996), and therefore in cultural values and religions. Lastovicka et al. (1999) gave examples from American Hindu, Buddhist, Christian/Jewish and Taoist values that show how frugal lifestyle is embedded in each. The literature is pertinent to the examination of the relationship between religious values and frugality; Hinduism (Lastovicka et al., 1999), Judaism (Longacre, 1980) and Christianity (Fisher, 1976) are found to be restrictive of acquisition, owning money and possessions. Quran, while being restrictive of excessive consumption like its counterparts, is supportive of its followers to wear their beautiful dresses when praying or when in public (Araf 7:31)[2]. While Lastovicka et al. (1999) approached frugality from a religious perspective as explained previously, they have mostly assumed that religiosity would cause non-consumption. Nevertheless, previous studies on the relationship between Islamic religiosity and quality consciousness and the Quranic verses suggest high levels of religiosity may very well have a positive effect on quality consciousness and therefore moderate the relationship of frugality to quality consciousness. Given previous studies that highlighted the positive relationship of religiosity to quality consciousness and addressing Lastovicka et al.'s (1999) call to further investigate the association between frugality and religiosity and their consequences, the following was hypothesized:

H3. Religiosity positively moderates the relationship of frugality to quality consciousness.

\section{Research methodology}

\subsection{Research context}

We argue that Turkey provides an appropriate context for our research on the interdependence of frugality and religiosity and their effect on quality consciousness. Turkish consumer has rapidly adopted the consumerist ideology despite Turkey's relatively recent transition to an open-market economy from a planned economy in the late 1980s. The transition to a liberal economy markets is closely tied to the rise of Islamism in the country (Onis, 1997). The feelings of resentment towards the Western lifestyle and consumption are due to negative events like bankruptcies and associated suicides experienced following the neoliberal policies of the 1980s. Turkish consumers who once heavily resented consumerism in general are adopting a Western lifestyle. Although the vast majority of the Turkish population are Muslim and that Islam is often associated with anti-consumerism, IPSOS Mori's (2014) cross-national study conducted in 20 countries showed that Turkey was the third most materialist country following India and China.

It seems that Turkey's adoption of materialistic values has also taken its toll economically. Turkey's saving rates dragged the anchor to an alarming rate of 14 per cent[3], with the second highest amount of monthly consumer goods import of $\$ 2,812,379,000$ in December 2013, since January of 1989 according to the Central Bank of Republic of Turkey[4]. Contrary to what would be expected, the spread of Islamist values that enforce frugal behaviour and warn against wasting in Turkey followed a rise of materialism and low 
saving rates. This outcome does not confirm the previous literature that equates Islam and frugality with anti-consumption or anti-consumerism. Therefore, to answer Zavestoski's (2002) and Cherrier's (2009) calls, the Turkish consumptionscape provides an interesting mean ordinary context to study the preferences of those who would ideally go against consumption.

\subsection{Pre-tests and measures}

This article empirically scrutinized the direct effect of frugality and religiosity on quality consciousness and the moderating effect of religiosity on this relationship. To measure religiosity, we used a 5-dimensional (i.e. ideological, ritualistic, intellectual, consequential, experiential) and 22-item scale (Rehman and Shabbir, 2010). Following past research, we opted for Lastovicka et al.'s (1999) eight-item single-factor frugality scale. Quality consciousness was measured using Sproles and Kendall's (1986) eight-item single factor scale. To eliminate any possible standard omitted variable bias (Clarke, 2005), quality consciousness was controlled for demographic variables that included age, education level, employment status, income, marital status, number of children and sex. The details of the measures that were used are presented in Table I.

We conducted a series of pre-tests. First, a randomly selected 30 non-student adults from five randomly selected municipalities in Istanbul evaluated the content and meaningfulness of the items. Next, we contacted four academicians for their comments on the utility of the items and revised the questionnaire according to their opinion.

\subsection{Sample and data collection}

The data were collected via face-to-face structured surveys. The procedure yielded a random sample of 413 (206 male and 207 females) non-student adults from five randomly selected of municipalities of İstanbul (Kadikoy: 87; Uskudar: 90; Bahcelievler: 80; Bayrampasa: 80; Gaziosmanpasa: 80). Although it was not intended, all respondents self-identified as Sunni Muslims which permitted this study to focus on a single consumer group. In total, 58 per cent of those in the sample were between 18 and 49 years of age. Further, 62 per cent of the respondents held at least a high school degree or higher; 32 per cent of respondents had a monthly net income higher than TL 3,000 (an approximate amount of $€ 1,000$ or higher), while 62 per cent was making below that amount a month. Further, 41 per cent of the sample was single, while 59 per cent was married. Finally, 39 per cent of respondents had no children, while 46 per cent had more than two. The detailed descriptive statistics, intercorrelations and the reliability statistics are presented in Table II.

\subsection{Method of analysis}

To investigate whether the relationship between frugality and quality consciousness is dependent on religiosity, the moderator, while controlling quality consciousness for demographic variables, a moderation analysis with multiple regressions via structural equations modelling was used (Frazier et al., 2004). To test the moderation effect of religiosity on the relationship of frugality to quality consciousness, maximum likelihood estimation was used on AMOS v.22. The tested model was presented in Figure 1.

To assess how well the structural model fits the data, several indices that may be categorized in three parts (absolute, incremental and parsimonious fit) were used. The absolute fit was evaluated using specifically chi-square and chi-square/degrees of freedom ratio, GFI, AGFI, RMSEA and PCLOSE. Incremental fit was examined using CFI, NFI, PCFI and PGFI. 
JIMA

8,2

\begin{tabular}{lll}
\hline Constructs & Descriptions & Ranging descriptions \\
\hline
\end{tabular}

Frugality

\section{0}

Islamic religiosity

Quality consciousness

Monthly net income

Age

Gender

Education

Number of children

Marital status

Table I.

Measures employed
Lastovicka et al. (1999) (e.g. There are things I resist buying today so I can save for tomorrow; Making better use of my own resources makes me feel good; I believe in being careful in how I spend my money)

Rehman and Shabbir (2010) (e.g. I have firm belief in all basic ideological dimensions of Islam; I regularly offer prayer five times a day; I always try to avoid minor and major sin; It is my duty to give respect to others and give them their rights according to Islamic Injunctions; I have feeling of being tempted by devil)

Sproles and Kendall's (1986) (e.g. Getting very good quality is very important to me; In general, I usually try to buy the best overall quality; A product doesn't have to be perfect, or the best, to satisfy me) On this card is an income scale on which 1 indicates $0-1500 \mathrm{TL}$ per month 6 the $5000 \mathrm{TL}+$ per month. We would like to know in what group you are. Please, specify the appropriate number, counting all wages, salaries, pensions and other incomes that come in

On this card is an age scale on which 1 indicates " 18 and below" and 6 indicates "60 and above". We would like to know in what group you are. Please, specify the appropriate number

By observation

On this card is an education scale on which 1 indicates "do not know how to read and write" 7 indicates "has a $\mathrm{PhD}$ ". We would like to know in what group you are. Please, specify the appropriate number

On this card is a number that indicates the number of children that you have. 1 indicates "do not have any children" and" 6 indicates "have $3+$ children. We would like to know in what group you are.

Please, specify the appropriate number On this card is a number that indicates your current marital status. 0 indicates "single" and 1 indicates, "married". We would like to know what group you are. Please, specify the appropriate number
Ranging from 1 to 5

$1=$ Completely disagree

$5=$ Completely agree

Ranging from 1 to 5

$1=$ Completely disagree

$5=$ Completely agree

Ranging from 1 to 5

$1=$ Completely disagree

$5=$ Completely agree

Ranging from 1 to 6

$1=0-1,500 \mathrm{TL}$

$5=5000 \mathrm{TL}+$

Ranging from 1 to 6

$1=18$ and below

$6=60+$

$1=$ Female

$0=$ Male

Ranging from 1 to 7

$1=$ Do not know how to read and write

$7=\mathrm{Has}$ a $\mathrm{PhD}$

Ranging from 1 to $61=\mathrm{I}$ do not

have any children

$6=3+$ children

Ranging from 0 to 1

$0=$ Single

$1=$ Married

\section{Results}

The structural model fits the data well $\left[\chi^{2}=29.632(20), p>0.05, \mathrm{GFI}=0.987\right.$, AGFI $=0.958$, RMSEA $=0.034$, PCLOSE $=0.841, \mathrm{CFI}=0.993, \mathrm{NFI}=0.973, \mathrm{PCFI}=0.360]$. We tested the hypotheses via moderated regression analysis. We mean-centred all variables to minimize 


\begin{tabular}{|c|c|c|c|c|c|c|c|c|c|c|c|}
\hline Variables & 1 & 2 & 3 & 4 & 5 & 6 & 7 & 8 & 9 & 10 & 1 doesn t \\
\hline \multicolumn{12}{|l|}{ 1. Married dummy } \\
\hline 2. Age & $0.575^{*}$ & & & & & & & & & & \\
\hline 3. Education & $-0.280^{*}$ & $-0.321^{*}$ & & & & & & & & & \\
\hline 4. Monthly net income & 0.077 & 0.087 & $0.303 *$ & & & & & & & & \\
\hline 5. Number of children & $0.643^{*}$ & $0.621 *$ & $-0.455^{*}$ & $-0.161 *$ & & & & & & & \\
\hline 6. Female dummy & 0.037 & $0.102^{*}$ & -0.043 & $-0.124^{*}$ & 0.079 & & & & & & 211 \\
\hline 7. Employed dummy & -0.005 & 0.070 & $0.161 *$ & $0.310^{*}$ & -0.060 & $-0.304 *$ & & & & & 21 \\
\hline 8. Quality consciousness & 0.034 & 0.005 & 0.047 & $0.104^{*}$ & -0.045 & 0.022 & $0.128^{*}$ & & & & \\
\hline 9. Frugality & 0.091 & 0.086 & $-0.191 *$ & $-0.549 *$ & $0.235^{*}$ & -0.018 & 0.001 & 0.059 & & & \\
\hline 10. Religiosity & $0.156^{*}$ & 0.002 & $-0.245^{*}$ & $-0.268^{*}$ & $0.275^{*}$ & 0.028 & $-0.183^{*}$ & 0.034 & $0.322^{*}$ & & \\
\hline Mean & 0.61 & 3.41 & 3.81 & 0.2 .04 & 1.35 & 0.501 & 0.74 & 3.39 & 3.97 & 3.81 & \\
\hline SD & $(0.48)$ & $(1.41)$ & $(0.82)$ & (1.49) & $(1.36)$ & $(0.50)$ & $(0.43)$ & (0.55) & $(0.62)$ & $(0.53)$ & Table II. \\
\hline Cronbach's $\alpha$ & & & & & & & & 0.680 & 0.867 & 0.897 & $\begin{array}{l}\text { Descriptive statistics, } \\
\text { intercorrelations and }\end{array}$ \\
\hline \multicolumn{11}{|c|}{ Note: *Intercorrelation significant at 0.05 level } & \\
\hline
\end{tabular}

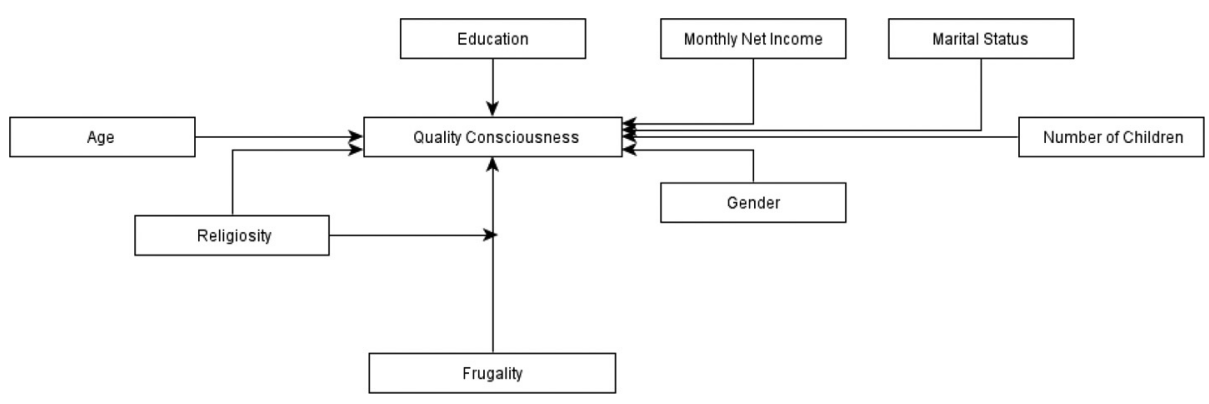

Figure 1. Research model

any possible threat of multicollinearity in equations where the interaction terms were included (Aiken and West, 1991). H1 posits that frugality should be positively related to quality consciousness. We found the relationship of frugality with quality consciousness to be statistically insignificant $(\beta=0.065 ; p>0.05)$, failing to support $H 1$. The scrutiny pertinent to $H 2$, which suggests that religiosity should be positively related to quality consciousness, was not supported $(\beta=-0.014 ; p>0.05)$. $H 2$ was therefore not supported. $H 3$ suggests that religiosity moderates the relationship of frugality to quality consciousness. We found that the interaction of frugality and religiosity is positively related to quality consciousness $(\beta=0.169 ; p<0.05)$. This finding supported our hypothesis that Islamic religiosity encourages quality consciousness and its moderator effect yields the relationship of frugality to quality consciousness to be statistically significant.

To further evaluate this finding, we conducted a simple slope test (Aiken and West, 1991) and plotted the graph of the interaction effect. We found that at high levels of religiosity, frugality is positively related to quality consciousness $(\beta=0.139 ; p<0.05)$, whereas at low levels of religiosity, frugality is not related to quality consciousness $(\beta=-0.027 ; p>0.05)$. Figure 2 shows the interaction effect.

An additional scrutiny was to provide evidence of possible direct effects of the demographic factors on quality consciousness. The results showed that income $(\beta=0.176$; $p<0.05)$ and the employment status dummy $(\beta=0.109 ; p<0.05)$ positively affected quality consciousness. The other control variables that included age $(\beta=-0.021 ; p=0.760)$, education level $(\beta=-0.008 ; p=0.894)$, number of children $(\beta=-0.114 ; p=0.140)$, marital 
JIMA

8,2

212

status $(\beta=0.076 ; p=0.261)$ and the female dummy $(\beta=0.087 ; p=0.092)$, all provided insignificant relations with quality consciousness. These results showed that quality consciousness as a phenomenon is more related to the variables that relate to the economic resources rather than economic needs (e.g. household size, marital status) and/or attitude forming variables (e.g. age and gender).

\section{Discussion and conclusion}

In response to calls (Cherrier, 2009; Zavestoski, 2002) to further scrutinize the preferences of those against consumption and in accordance with Lastovicka et al.'s (1999) approach to frugality, this study examined the interrelationships of frugality, religiosity and quality consciousness. Although religiosity is highlighted as one of five perspectives that frugality may be approached from (Lastovicka et al., 1999), researchers have mostly studied the two phenomena separately and associated them with abstinence from consuming in general individually. Based on Lastovicka et al.'s (1999) very definition of frugality, we have conceptualized frugality as a lifestyle trait that leads to quality consciousness that prevents consumption impulses. Our study, however, failed to provide any supporting evidence on the relationship of frugality to quality consciousness. Similarly, while most would consider religiosity as an inherently anti-capital, anti-consumption and anti-consumerist notion, a closer look to extant literature shows that religiosity is associated to quality consciousness. Our results, however, did not provide similar results. We have failed to discover a significant direct relationship of religiosity to quality consciousness.

Lastovicka et al.'s (1999) and Belk's (1983) takes on religiosity suggest that religious individuals would stick to a frugal lifestyle to reach a higher consciousness. While what is meant by higher consciousness implies spiritual growth through extreme non-consumption, our results showed that the higher consciousness also relates to religious' frugal marketplace preferences. Our analyses provided empirical evidence that religiosity positively moderates the frugality-quality consciousness association. Additional results showed a significant and positive relationship of frugality to quality consciousness at high levels of religiosity while providing insignificant results at low levels of religiosity. Our results therefore advance knowledge on the consumption preferences on those who supposedly decide to go against consumption by providing evidence on the frugality-religiosity-quality consciousness association. Ahmed and Sara (2004), Gellner, (1992) and Turner (1994) equate Islamic religiosity with the rejection of consumption. Our results do not dispute this claim but develop knowledge on the consumption preferences of highly religious consumers that adopt a more frugal way of life.

Our results show that frugal traits of those with high levels of adherence translate into quality consciousness. Recent research that focused on the Islamic consumption practices within predominantly Western, Christian markets (Belk and Ger, 1994; Belk et al., 1997; Ger and Belk, 1999) show the dynamic nature of Islamic consumptionscape (Wilson et al., 2013). Wilson et al. (2013) draw the attention to an emerging unifying global Muslim identity

Figure 2.

Interaction effect

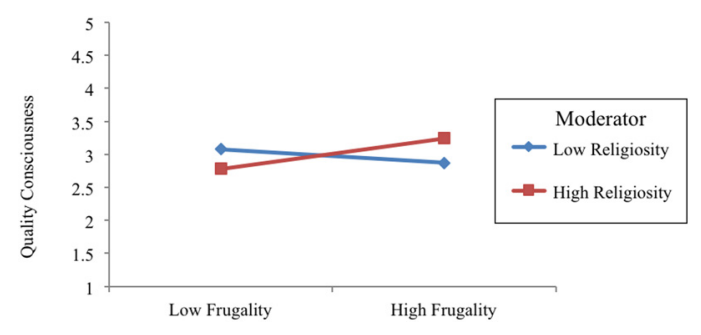


that crosses socio-economic groups, ethnicities and nations where the idea of modesty is being redefined from a misery approximating refrain from consuming to a visible modest beauty. Similarly, Sandikci and Ger (2010) show that Muslims craft a new, hybrid consumer identity that is modern and religious, tasteful and modest. Our study provides the empirical support to the extant literature and shows that highly religious individuals, instead of refraining from consumption, develop a quality consciousness.

We recognize the limitations of using a cross-sectional study conducted within the bound of a single belief system (Islam). At the very least, however, our study points to the possibility that highly religious individuals' frugal lifestyles would direct them to cultivate a quality-conscious identity. This indicates that the religious frugal consumers prioritize quality in products and services that they would purchase. The religious frugal consumers may consider consumptions that are made on impulse a waste and sacrifice (non-consumption) until they can afford the quality that they seek. Considering that the religious frugal consumers are inclined to be quality-conscious, future research may focus on the association of frugality with nonbrand choice such as the purchase of strategic items as Lastovicka et al. (1999) suggested. Similarly, the scrutiny of whether frugality plays a role in the suggested relationship between Islamic religiosity and prosocial behaviour (e.g. charitable behaviour) (Opoku, 2013; Arli and Lasmono, 2015) may prove to be a fruitful area of research.

\section{Notes}

1. The list is not exhaustive. For more details on the recent phenomena in the Muslim world, see Wilson et al. (2013).

2. The English translation of Araf 31:7: O children of Adam! Wear your beautiful apparel at every time and place of prayer: eat and drink: but waste not by excess for Allah loveth not the wasters.

3. Last accessed on 25.01.2015: http://data.worldbank.org/indicator/NY.GDS.TOTL.ZS

4. Last accessed on 25.01.2015: http://evds.tcmb.gov.tr/

\section{References}

Ahmed, S. and Sara, A. (2004), The Cultural Politics of Emotion, Taylor \& Francis, New York, NY.

Aiken, L.S. and West, S.G. (1991), Multiple Regression: Testing and Interpreting Interactions, 3rd ed, Sage Publications, London.

Albinsson, P.A., Wolf, M. and Kopf, D.A. (2010), "Anti-consumption in East Germany: consumer resistance to hyperconsumption", Journal of Consumer Behaviour, Vol. 9 No. 6, pp. 412-425.

Amin, H., Rahim Abdul Rahman, A. and Abdul Razak, D. (2014), "Consumer acceptance of Islamic home financing”, International Journal of Housing Markets and Analysis, Vol. 7 No. 3, pp. 307-332.

Arli, D. and Lasmono, H. (2015), "Are religious people more caring? Exploring the impact of religiosity on charitable organizations in a developing country", International Journal of Nonprofit and Voluntary Sector Marketing, Vol. 20 No. 1, pp. 38-51.

Bagozzi, R.P. (1978), "The construct validity of the affective, behavioral, and cognitive components of attitude by analysis of covariance structures", Multivariate Behavioral Research, Vol. 13 No. 1, pp. 9-31.

Bailey, J.M. and Sood, J. (1993), “The effects of religious affiliation on consumer behavior: a preliminary investigation”, Journal of Managerial Issues, Vol. 5 No. 3, pp. 328-352.

Belk, R.W. (1983), "Worldy possessions: issues and critisims", in Bagozzi, R.P., Tybout, A.M. and Abor, A. (Eds), Association for Consumer Research, Advances in Consumer Research, MI, Vol. 10, pp. 514-519.

Frugal doesn't mean ordinary

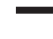


JIMA

8,2

214

Belk, R.W. and Ger, G. (1994), "Problems of marketization in Romania and Turkey", in Shultz, C. II, Belk, R. and Ger, G. (Eds), Consumption in Marketizing Economies, JAI Press, Greenwich, CT, pp. 123-156.

Belk, R.W., Ger, G. and Askegaard, S. (1997), “Consumer desire in three cultures: results from projective research", in Brucks, M. and MacInnis, D.J. (Eds), Advances in Consumer Research, Association for Consumer Research, Provo, UT, Vol. 24, pp. 24-28.

Birkner, C. (2013), "Thrifty brits: economic austerity in the UK has given rise to a more frugal British consumer", Marketing News, 8 August.

Bouckaert, L., Opdebeeck, H.J. and Zsolnai, L. (Eds) (2008), Frugality: Rebalancing Material and Spiritual Values in Economic Life, Verlag Peter Lang, Bern.

Cherrier, H. (2009), "Disposal and simple living: exploring the circulation of goods and the development of sacred consumption", Journal of Consumer Behaviour, Vol. 8 No. 6, pp. 327-339.

Clarke, R.J. (2005), "Research methodologies”, Presented at the University of Wollowong, HDR Seminar Series by Faculty of Commerce, available at:www.uow.edu.au/content/groups/public/@web/@ commerce/documents/doc/uow012042.pdf

Egol, M., Clyde, A., Rangan, K. and Sanderson, R. (2010), "The new consumer frugality: adapting to the enduring shift in U.S. consumer spending and behavior", Booz \& Company, 24 February, available at: www.booz.com/media/uploads/he_New_Consumer_Frugality.pdf (accessed 10 May 2015).

Engel, M. (1976), “The future of aesthetic education”, Art Education, Vol. 29 No. 3, pp. 29-33.

Essoo, N. and Dibb, S. (2004), "Religious influences on shopping behaviour: an exploratory study", Journal of Marketing Management, Vol. 20 Nos 7/8, pp. 683-712.

Faber, R.J. and O'Guinn, T.C. (1992), “A clinical screener for compulsive buying”, Journal of Consumer Research, Vol. 19 No. 3.

Fealy, G. and White, S. (2008), Expressing Islam Religious Life and Politics in Indonesia, Institute of Southeast Asian Studies (ISEAS), Singapore.

Fischer, J. (2008), Proper Islamic Consumption: Shopping Among the Malays in Modern Malaysia, Nordic Institute of Asian Studies, Copenhagen.

Fisher, W.E. (1976), A New Climate for Stewardship, Abbingdon, Nashville.

Flynn, L.R. and Goldsmith, R.E. (2016), "Introducing the super consumer", Journal of Consumer Behaviour, Vol. 15 No. 3, pp. 201-207.

Frazier, P.A., Tix, A.P. and Barron, K.E. (2004), "Testing moderator and mediator effects in counseling psychology research", Journal of Counseling Psychology, Vol. 51 No. 1, pp. 115-134.

Gellner, E. (1992), Postmodernism, Reason and Religion, Routledge, New York, NY.

Ger, G. and Belk, R.W. (1999), "Accounting for materialism in four cultures”, Journal of Material Culture, Vol. 4 No. 2, pp. 183-204.

Hadaway, C.K. and Roof, W.C. (1978), "Religious commitment and the quality of life in American society", Review of Religious Research, Vol. 19 No. 3.

Harrison, D.A., Price, K.H. and Bell, M.P. (1998), "Beyond relational demography: time and the effects of surface- and deep-level diversity on workgroup cohesion", Academy of Management Journal, Vol. 41, pp. 96-107.

Hasan, Z. (2005), "Treatment of consumption in Islamic economics: an appraisal”, Journal of King Abdulaziz University-Islamic Economics, Vol. 18 No. 2, pp. 29-46.

Hasan, Z. (2006), Introduction to Microeconomics: An Islamic Perspective, Pearson/Prentice Hall, NJ.

Inglehart, R. and Baker, W.E. (2000), "Modernization, cultural change, and the persistence of traditional values", American Sociological Review, Vol. 65 No. 1, pp. 19-52.

Ipsos Mori (2014), “Global trends survey”, available at: www.ipsosglobaltrends.com/ (accessed 1 June 2015). 
Johnson, B.R., Jang, S.J., Larson, D.B. and De Li, S. (2001), "Does adolescent religious commitment matter? A re-examination of the effects of religiosity on delinquency", Journal of Research in Crime and Delinquency, Vol. 38 No. 1, pp. 22-44.

JWT (2009), "Understanding the Islamic consumer", available at: www.wpp.com/NR/rdonlyres/0EE12 2EE-C956-431A-BFC9-78BED42011D1/0/marketing_to_muslims.pdf

Kahf, M. (1992a), "A contribution to the theory of consumer behaviour in Islamic society”, in Tahir, S., Ghazaly, A. and Syed Agil, S.O. (Eds), Readings in Microeconomics in Islamic Perspective, Longman, Sdn Bhd, pp. 90-103.

Kahf, M. (1992b), "The theory of consumption", in Tahir, S., Ghazaly, A. and Syed Agil, S.O. (Eds), Readings in Microeconomics in Islamic Perspective, Longman, Sdn Bhd, pp. 61-68.

Kahf, M. (2002), "Strategic trends in the Islamic banking and finance movement", Proceedings of the Fifth Annual Forum of Harvard Program on Islamic Finance and Banking, Harvard University Press, Cambridge, $M A$.

Kahf, M. (2004), "Islamic banks: the rise of a new power alliance of wealth and Shari'a scholarship", in Henry, C. and Wilson, R. (Eds), The Politics of Islamic Finance, Edinburgh University Press, Edinburgh, pp. 17-36.

Kearney, A.T. (2007), "Addressing the Muslim market", available at: www.atkearney.com/images/ global/pdf/AddressingMuslimMarket_S.pdf

Khan, M.F. (1984), "Macro consumption function in an Islamic framework", Journal of Research in Islamic Economics, Vol. 1 No. 2, pp. 1-24.

Khan, M.F. (1991), "Time value of money and discounting in Islamic perspective”, Review of Islamic Economics, Vol. 1, No. 2, pp. 25-45.

Kotler, P. (1972), “A generic concept of marketing”, Journal of Marketing, Vol. 36 No. 2, pp. 46-54.

Kotz, D. (2009), "The financial and economic crisis of 2008: a systemic crisis of neoliberal capitalism', Review of Radical Political Economics, Vol. 41 No. 3, pp. 305-317.

Lastovicka, J.L., Bettencourt, L.A., Hughner, R.S. and Kuntze, R.J. (1999), "Lifestyle of the tight and frugal: theory and measurement”, Journal of Consumer Research, Vol. 26 No. 1, pp. 85-98.

Lichtenstein, D.R., Netemeyer, R.G. and Burton, S. (1990), "Distinguishing coupon proneness from value consciousness: an acquisition-transaction utility theory perspective", Journal of Marketing, Vol. 54 No. 3, pp. 54-67.

Longacre, D.J. (1980), Living More with Less: A Pattern for Living with Less and a Wealth of Practical Suggestions from the Worldwide Experiences of Mennonites, Hodder and Stoughton, London.

McDaniel, S.W. and Burnett, J.J. (1990), "Consumer religiosity and retail store evaluative criteria", Journal of the Academy of Marketing Science, Vol. 18 No. 2, pp. 101-112.

Mokhlis, S. (2009), "Relevancy and measurement of religiosity in consumer behavior research", International Business Research, Vol. 2 No. 3, pp. 75-84.

Mokhlis, S. (2010), "Religious contrasts in consumer shopping styles: a factor analytic comparison", Journal of Business Studies Quarterly, Vol. 2 No. 1, pp. 52-64.

Ogilvy and Mather (2010), Brands, Islam and the New Muslim Consumer, Ogilvy and Mather, available at: www.ogilvy.com/News/Press-Releases/May-2010-The-Global-Rise-of-the-New-MuslimConsumer.aspx

Onis, Z. (1997), "The political economy of Islamic resurgence in Turkey: the rise of the Welfare Party in perspective", Third World Quarterly, Vol. 18 No. 4, pp. 743-766.

Opoku, R.A. (2013), "Examining the motivational factors behind charitable giving among young people in a prominent Islamic country", International Journal of Nonprofit and Voluntary Sector Marketing, Vol. 18 No. 3, pp. 172-186. 
JIMA

8,2

216

Pew Research Center (2013), “The world's Muslims: religion, politics and society”, Pew Research Center's Religion \& Public Life Project, available at: www.pewforum.org/2013/04/30/the-worldsmuslims-religion-politics-society-overview/ (accessed 30 August 2015).

Pink, J. (2010), Muslim Societies in the Age of Mass Consumption: Politics, Culture and Identity Between the Local and the Global, 1st ed, Cambridge Scholars Publishing, Newcastle Upon Tyne.

Prahalad, C.K. (2004), The Fortune at the Bottom of the Pyramid, Wharton School Publishing, Upper Saddle River, NJ.

Rehman, A. and Shabbir, M.S. (2010), “The relationship between religiosity and new product adoption”, Journal of Islamic Marketing, Vol. 1 No. 1, pp. 63-69.

Reuters, T. and Standard, D. (2014), "State of the global Islamic economy 2014-2015 report”, available at: http://halalfocus.net/wp-content/uploads/2015/01/SGIE-Report-2014.pdf

Richins, M.L. and Dawson, S. (1992), "A consumer values orientation for materialism and its measurement: scale development and validation”, Journal of Consumer Research, Vol. 19 No. 3, pp. 303-316.

Rick, S.I., Cryder, C.E. and Loewenstein, G. (2008), "Tightwads and spendthrifts”, Journal of Consumer Research, Vol. 34 No. 6, pp. 767-782.

Riquelme, H.E., Rios, R.E. and Al-Sharhan, N. (2011), “Antecedents of ostentatious consumption in Kuwait”, Journal of Islamic Marketing, Vol. 2 No. 3, pp. 295-308.

Rose, P., Smith, S.T. and Segrist, D.J. (2010), "Too cheap to chug: frugality as a buffer against college-student drinking", Journal of Consumer Behaviour, Vol. 9 No. 3, pp. 228-238.

Said, E. (1978), Orientalism, 1st ed., Pantheon Books, New York, NY.

Sandikci, Ö. and Ger, G. (2002), "In-between modernities and postmodernities: theorizing Turkish consumptionscape", in Susan, M.B., Kent, N. and Valdosta, G.A. (Eds), Advances in Consumer Research, Vol. 29, pp. 465-470.

Sandikci, Ö. and Ger, G. (2010), "Veiling in style: how does a stigmatized practice become fashionable?”, Journal of Consumer Research, Vol. 37 No. 1, pp. 15-36.

Sandikci, Ö. (2011), "Researching Islamic marketing: past and future perspectives”, Journal of Islamic Marketing, Vol. 2 No. 3, pp. 246-258.

Shama, A. (1981), "Coping with stagnation: voluntary simplicity", Journal of Marketing, Vol. 45 No. 3, doi: $10.2307 / 1251547$.

Shoham, A. and Brenèiè, M.M. (2004), "Determinants of the consumption of cultural events", Journal of Euro marketing, Vol. 13 Nos 2/3, pp. 29-47.

Sood, J. and Nasu, Y. (1995), "Religiosity and nationality", Journal of Business Research, Vol. 34 No. 1, pp. 1-9.

Sproles, G.B. and Kendall, E.L. (1986), “A methodology for profiling consumers” decision-making styles', Journal of Consumer Affairs, Vol. 20 No. 2, pp. 267-279.

Teimourpour, B. and Heidarzadeh Hanzaee, K. (2011), "The impact of culture on luxury consumption behaviour among Iranian consumers", Journal of Islamic Marketing, Vol. 2 No. 3, pp. 309-328.

Todd, S. and Lawson, R. (2003), "Towards an understanding of frugal consumers", Australasian Marketing Journal (AMJ), Vol. 11 No. 3, pp. 8-18.

Turner, S.P. (1994), 2nd ed, The Social Theory of Practices: Tradition, Tacit Knowledge, and Presuppositions, University of Chicago Press, Chicago.

Wilk, R.R. (1996), Economies and Cultures: Foundations of Economic Anthropology, Westview Press, Boulder, CO.

Wilson, J.A. and Hollensen, S. (2013), "Assessing the implications on performance when aligning customer lifetime value calculations with religious faith groups and after lifetime values-a Socratic elenchus approach", International Journal of Business Performance Management, Vol. 14 No. 1, pp. 67-94. 
Wilson, J.A., Belk, R.W., Bamossy, G.J., Sandikci, Ö., Kartajaya, H., Sobh, R. and Scott, L. (2013), "Crescent marketing, Muslim geographies and brand Islam: reflections from the JIMA Senior Advisory Board", Journal of Islamic Marketing, Vol. 4 No. 3, pp. 22-50.

Youn, S. and Faber, R. (2000), "Impulse buying: its relation to personality traits and cues", Advances in Consumer Research, Vol. 27 No. 1, pp. 179-185.

Yousaf, S. and Malik, M.S. (2013), "Evaluating the influences of religiosity and product involvement level on the consumers", Journal of Islamic Marketing, Vol. 4 No. 2, pp. 163-186.

Zavestoski, S. (2002), "Guest editorial: anti-consumption attitudes”, Psychology and Marketing, Vol. 19 No. 2, pp. 121-126.

\title{
Further reading
}

Central Bank of the Republic of Turkey (2015), "Türkiye Cumhuriyeti Merkez Bankasý Electronic Data Delivery System", available at: http://evds.tcmb.gov.tr/ (accessed 25 January 2015).

Egol, M., Clyde, A., Rangan, K. and Sanderson, R. (n.d.), "The new consumer frugality: adapting to the enduring shift in US consumer spending and behavior", White Paper, available at: Booz. \& Company: www.booz.com/media/ uploads/ he_New_Consumer_Frugality.pdf

Kamaruddin, A.R. (2009), "Religiosity and cross-cultural analysis of shopping behavior among Malaysian and Thai consumer", 2nd International Conference on Marketing \& Retailing, UiTM Malacca, 8-10 July.

Qur'an, T.T., Calendar, P.D. and Editors of Tahrike Tarsile Qur'an (2007), Inspirations from the Qur'an: A Perpetual Calendar, Tahrike Tarsile Qur'an, New York, NY.

The World Bank (2015), "Gross domestic savings (\% of GDP) | Data | Table”, available at: http://data. worldbank.org/indicator/NY.GDS.TOTL.ZS (accessed 25 January 2015).

Thomson Reuters (2014), State of the Global Islamic Economy 2014-2015, Thomson Reuters, available at: www.zawya.com/ifgpublications/Thomson_Reuters_State_of_the_Global_Islamic_ Economy_Report_20142015-251114170832G/ (accessed 10 October 2015).

\begin{abstract}
About the authors
Volkan Yeniaras obtained both MSc and PhD in Marketing from Swansea University, UK. He is currently an Assistant Professor of Marketing at Kadir Has University, Istanbul. His research interests lie in the effect of religiosity on various consumer behaviours. Volkan Yeniaras is the corresponding author and can be contacted at: vyeniaras82@gmail.com

Tugra Nazli Akarsu is a Doctoral Candidate at Department of Marketing, Branding and Tourism, Middlesex University Business School London. She received her bachelor's degree in Business Administration from Koc University, Istanbul, and a master's degree in Business Administration from Kadir Has University, Istanbul. Her research interests lie in the area of sensory branding, the impact of consumer religiosity on perception and various consumer behaviours.
\end{abstract}

For instructions on how to order reprints of this article, please visit our website:

www.emeraldgrouppublishing.com/licensing/reprints.htm

Or contact us for further details: permissions@emeraldinsight.com 